\title{
OBSERVATION OF THE BENEFITS OF EAR MASSAGE THERAPY SKILLS IN EAST JAVA
}

\section{Nyilo Purnami*1 ${ }^{1}$, Suhariningsih ${ }^{2}$, Myrna Adianti $^{2}$, Maya Septriana ${ }^{2}$, Edith Frederika ${ }^{2}$, Dwi Indah Puspita ${ }^{2}$}

${ }^{1}$ Department of Otorhinolaryngology Head and Neck Surgery, Faculty of Medicine, Universitas Airlangga, Indonesia, ${ }^{2}$ Sentra Penapisan Dan Pengembangan Penyehat Tradisional (SP3T) Provinsi Jawa Timur, Dinas Kesehatan Provinsi Jawa Timur, Indonesia.

ABSTRACT
The high number of patients who come for ear therapy with
massage skills, the P3T Center intends to carry out an
observational screening of ear therapy. This screening aims to
find out how the diagnostic method and application of ear therapy
with massage skills and the benefits of ear therapy to overcome
the problem of hearing loss (hearing impairment). This screening
design uses an observational method in which the researcher
makes observations and interviews with respondents. Data
collection techniques were carried out by looking at the results of
the examination of respondents' hearing tests and the results of
interviews with respondents. Patient therapy results in 18 people
(60\%) no progress or the same as the original condition. this
shows that therapy can be said to be ineffective in curing ear
disorders. The results of the audiometry examination of the right
and left ear stated that none of the patients was normal. Even
though there are patients who claim to be able to hear loud sounds
in the questionnaire, it is not supported by audiometry results. So
it can be concluded that ear therapy with massage skills has no
impact on patients suffering from hearing loss.

\section{ARTICLE HISTORY}

Received: May 5, 2020 Revised: June 25, 2020 Accepted: July 13, 2020 Published: August 30, 2020 (Online)

doi: 10.20473/jcmphr.v1i2.21694

\section{KEYWORDS}

Ear massage, hearing loss

\section{CORRESPONDING}

\section{AUTHOR}

Nyilo Purnami $\triangle$ nyilo@fk.unair.ac.id Department of Ear Nose Throat (ENT) - Head Neck Surgery, Faculty of Medicine, Universitas Airlangga -

Dr. Soetomo General Academic Hospital, Indonesia,

Jl. Mayjend Prof. Dr. Moestopo 4-6, Surabaya, Indonesia

\section{INTRODUCTION}

Deaf is someone who has a barrier in hearing function and lasts only temporarily and permanently. ${ }^{1}$ Congenital deafness can be caused by genetic mutations, parent ancestry, or exposure to disease while still in the womb. ${ }^{2}$ While hearing impairment that occurs after birth can be caused by loud sounds in the long term/long, age (aging), injury, and certain diseases such as infections. ${ }^{3}$ The Southeast Asian region is a region with a high number of cases of hearing loss and deafness, so WHO has launched the "Sound Hearing 2030" program. ${ }^{4}$ There are 2 ways to use assistive devices, including cochlear implants implanted in the ear through surgery, as well as hearing aids that can be mounted and removed as desired. ${ }^{5}$

The high number of patients who come for ear treatment with massage skills for deaf cases both deaf from birth, as well as hearing impairment due to illness (and or aging), then the Center of P3T intends to do obervasional screening about the ear therapy. In order to be able to elevate the nation's local wisdom by exploring how to diagnose and handle ear therapy from massage skill. 


\section{MATERIALS AND METHODS}

This screening used an observational screening design by conducting observations and interviews with respondents registered as ear therapy patients with massage skills and conducting hearing tests on respondents. The screening time is carried out for 4 months starting from June to September 2019.

Audiometry tests were conducted in 2 different places, the first at SLB AB Kemala Bhayangkara 2 Gresik and at the Hastind Hearing Aid Center in Surabaya. Sampling is done randomly and the required sample (according to the minimum number of samples) is 30 people.

Samples obtained amounted to 13 people from Gresik and 17 people from Surabaya. The inclusion criteria of this study are respondents who have hearing loss as evidenced by the results of audiometry and are willing to be respondents until the end. The data that has been collected is then analyzed.

The instrument used in this study is audiometry. Data collection techniques carried out by looking at the results of the examination of respondents' hearing tests and the results of interviews with respondents. Descriptive test is used to display the results of the patient's characteristic data and the results of the patient's examination.

\section{RESULTS}

The total number of patients who were willing to be interviewed and conducted audiometric tests was 32 patients, but there were 2 patients who did not want to provide complete data. The total number of inclusion patients was 30 people and the exclusion of 2 people, along with the screening results that had been done. Respondent characteristics data consisting of age and gender range characters are shown below.

Table 1. Respondent characteristic data

\begin{tabular}{lc}
\hline \multicolumn{1}{c}{ Variable } & $\begin{array}{c}\text { Number } \\
(\mathbf{n}=\mathbf{3 0})\end{array}$ \\
\hline $\begin{array}{l}\text { Age (years) } \\
12-25\end{array}$ & $13(43.3 \%)$ \\
Gender & \\
Female & \\
Male & $13(43.3 \%)$ \\
\hline
\end{tabular}

The age range of patients varies from the age of the child to the adult age. The most age-old treatment was teenagers as many as 13 people $(43.3 \%)$ aged $12-25$ years. The most patients were male with 17 people $(56.7 \%)$, while women were 13 people $(43.3 \%)$.

Data on the characteristics of the respondent's examination and therapy results are the results of audiometry examination, duration of therapy and the results of the therapy shown in the table below. 
Table 2. Characteristics of Audiometry test results

\begin{tabular}{lcc}
\hline Degree of Hearing loss & Number & Percentage \\
\hline Audiometry results left ear & 3 & $11.5 \%$ \\
Moderate & 2 & $7.7 \%$ \\
Moderate to severe & 7 & $26.9 \%$ \\
Severe & 14 & $53.8 \%$ \\
Profound & & \\
Audiometry results right ear & 3 & $11.1 \%$ \\
Moderate & 2 & $7.4 \%$ \\
Moderate to severe & 7 & $25.9 \%$ \\
Severe & 15 & $55.6 \%$ \\
Profound & & \\
\hline
\end{tabular}

The results of the audiometry examination of the right ear stated that the very heavy ear category was 15 people $(55.6 \%)$, the weight category was 7 people $(25.9 \%)$, the moderate-heavy category was 2 people $(7.4 \%)$, the moderate category was 3 $(11.1 \%)$ people and 3 people did not experience right ear disorders. The results of the audiometry examination of the right ear stated that none of the patients were normal. Even though there are patients who claim to be able to hear loud sounds in the questionnaire, it is not supported by audiometry results. So it can be concluded that ear therapy has no impact on patients suffering from right ear disorders. The results of the audiometry examination of the left ear stated that the very heavy category was 14 people (53.8\%), the weight category was 7 people $(26.9 \%)$, the moderate-heavy category was 2 people (7.7\%), the moderate category was 3 people $(11.5 \%)$ and 4 people did not have a left ear disorder. The results of the audiometry examination of the left ear stated that none of the patients were normal. Even though there are patients who claim to be able to hear loud sounds in the questionnaire, it is not supported by audiometry results. So it can be concluded that ear therapy has no impact on patients suffering from left ear disorders.

\section{Table 3. Distribution of Duration therapy and therapy result}

\begin{tabular}{lcc}
\hline Duration and Results & Number & Precentage \\
\hline Duration of theraphy & 5 & \\
$1-2$ therapy & 5 & $16.7 \%$ \\
$3-4$ therapy & 7 & $16.7 \%$ \\
$5-6$ therapy & 13 & $23.3 \%$ \\
$>6$ therapy & & $43.3 \%$ \\
Theraphy Results & 8 & \\
Can hear sounds but very soft & 0 & $26.7 \%$ \\
can hear sound but softly & 4 & $0 \%$ \\
can hear loud sound & 18 & $60 \%$ \\
no progress or same as the original condition & & \\
\hline
\end{tabular}

Whereas the duration of therapy for most patients was $>6$ times of therapy, namely 13 patients $(43.3 \%), 5-6$ times as many as 7 patients $(23.3 \%)$, and patients who treated 3-4 times and 1-2 times each therapy - 5 patients $(16.7 \%)$ each. The results of therapy for patients 4 people can hear loud sounds $(13.3 \%), 8$ people can hear but very slowly $(26.7 \%)$ and 18 people $(60 \%)$ have no progress / same as the original condition. More than $50 \%$ of patients said there was no progress / the same as the original condition, this shows that therapy can be said to be ineffective to cure ear disorders. 


\section{DISCUSSION}

The age of most who treated was 12-25 years old and male sex. The most audiometry results of the left and right ear are very severe hearing loss category. In America more than 35 million people aged 18 years and over experience hearing loss and get worse with age. At the age of less than 41 years many hearing loss occurs due to the development and advancement in technology such as tend to listen to music using a headset. At a productive age, hearing loss occurs due to frequent exposure to noise. This may also cause a lot of hearing loss in the male sex. ${ }^{6}$ Gender can also affect the incidence of hearing loss, men have a 3 times greater risk than women to experience hearing loss due to noise. ${ }^{7-8}$

The most duration of therapy was $<6$ times the therapy but it was obtained the results of therapy with audiometry examination again showed no progress or the same as the original condition. This shows that ear massage therapy is not effective to cure ear disorders. Ear massage therapy is a relatively new development in medical care enabling deaf people to once again receive a sound sensation (unlike hearing aids) which makes the sound louder. Ear massage is possible to stimulate the auditory nerve, hair cells and there by producing sound sensations in different ways. ${ }^{9}$ The results of ear massage therapy regenerate hair cells in the cochlea and renew hearing in cases of hearing loss of sensory nerves. but massage therapy is not an absolute treatment for hearing loss. To be able to hear again still have to use hearing aids. ${ }^{9}$ This supports that massage therapy cannot treat hearing loss. ${ }^{10}$ However, this study also conducted interviews, where the results of the questionnaire filling interviews found there are patients who claim to be able to hear loud sounds, but that is not supported by audiometry results. This may be due to ear massage provides relaxation to the patient.

The results of the audiometry examination of the right and left ear stated that none of the patients was normal. Even though there are patients who claim to be able to hear loud sounds in the questionnaire, it is not supported by audiometry results so that it can be concluded that ear therapy with massage skills has no impact on patients suffering from ear disorders.

\section{ACKNOWLEDGMENT}

The Authors would like to thank the Dinas Kesehatan Jombang and the sentra penapisan dan pengembangan penyehat tradisional (SP3T) Province East Java.

\section{REFERENCES}

1. Cunningham, LL. Tucci, DL. 2017. Hearing Loss in Adults. The New England Journal of Medicine, Dec 21, 377(25), 2465-2473.

2. Isaacson, B. 2010. Hearing Loss. Medical Clinics of North America. 94(5), 973-988.

3. American with Disabilities (ADA). 2006. Communicating with People Who Are Deaf or Hard of Hearing. ADA Guide for Law Enforcement Officers..

4. Centers for Disease Control and Prevention (CDC). 2018. Hearing Loss in Children: Treatment and Intervention Services.

5. National Institute on Deafness and Other Communication Disorders (NIDCD). 2017. Hearing Aids. Health A-Z. Hearing loss.

6. Marisdayana, Rara. Suhartono. Nurjazuli. 2016. Hubungan Intensitas Paparan Bising Dan Masa Kerja Dengan Gangguan Pendengaran Pada Karyawan PT. X”, Jurnal Kesehatan Lingkungan Indonesia.15(1), $22-27$. 
7. Eryani, Yesti Mulia. Wibowo, Catur Ari. Saftarina, Fitria, 2017. Faktor Risiko Terjadinya Gangguan Pendengaran Akibat Bising, Medula. 7(4), 112-117.

8. Dewi, Yussy Afriani and Agustian, Ratna Anggraeni. 2012. Skrining Gangguan Dengar pada Pekerja Salah Satu Pabrik Tekstil di Bandung”, Majalah Kedokteran Bandung 44(2), 96100.

9. Hon, Nana Saheb. 2012. A Clinical Study of Massaging Pressure Therapy for Management of Sensoryneural Hearing Loss. IOSR Journal of Dental and Medical Sciences 4(2), 6-11.

10.Rodriguez-Mansilla J, Gonzalez-LopezArza MV, Varela-Donoso E, Montanero-Fernandez J, JimenezPalomares M, Garrido-Ardila EM. 2013. Ear therapy and massage therapy in the elderly with dementia: a pilot study. J Tradit Chin Med. 3, 461-467. 